\author{
JURNAL EKONOMI \\ EFEKTIF
}

ISSN : $2622-8882$, E-ISSN : 2622-9935

Jurnal Ekonomi Efektif, Vol. 2, No. 4, Juli 2020

@Prodi Manajemen Fakultas Ekonomi Universitas

Pamulang

\title{
PENGARUH RETURN ON ASSET TERHADAP EARNING PER SHARE PADA PT. MANDOM INDONESIA, TBK PERIODE 2012-2020
}

\author{
Kartono \\ Universitas Pamulang, Tangerang Selatan, Banten Indonesia \\ *dosen01012@unpam.ac.id
}

\begin{abstract}
ABSTRAK
Penelitian ini bertujuan untuk mengetahui pengaruh Return On Asset terhadap Earning Per Share pada PT. Mandom Indonesia, Tbk. Metode yang digunakan adalah explanatory research. Teknik analisis menggunakan analisis statistik dengan pengujian regresi, korelasi, determinasi dan uji hipotesis. Hasil penelitian ini variabel Return On Asset diperoleh nilai rata-rata sebesar 12,72\%. Variabel Earning Per Share diperoleh nilai rata-rata 792,11. Return On Asset berpengaruh positif dan signifikan terhadap Earning Per Share dengan nilai persamaan regresi $\mathrm{Y}=-106,130+70,579 \mathrm{X}$, dan nilai koefisien korelasi 0,676 atau memiliki tingkat hubungan yang kuat dengan nilai determinasi 45,7\%. Uji hipotesis diperoleh signifikansi 0,046<0,05.
\end{abstract}

Kata Kunci: Return On Asset, Earning Per Share.

\section{ABSTRACT}

This study aims to determine the effect of Return On Asset on Earning Per Share at PT. Mandom Indonesia, Tbk. The method used is explanatory research. The analysis technique uses statistical analysis with regression testing, correlation, determination and hypothesis testing. The results of this research variable Return On Asset obtained an average value of $12.72 \%$. The variable Earning Per Share obtained an average value of 792.11. Return On Asset has a positive and significant effect on Earning Per Share with the regression equation value $Y=-106,130+70,579 X$, and the correlation coefficient value of 0.676 or has a strong level of relationship with a determination value of 45.7\%. Hypothesis testing obtained a significance of $0.046<0.05$.

Keywords: Return On Asset, Earning Per Share. 


\section{PENDAHULUAN}

\section{A. Latar Belakang Masalah}

Berdirinya sebuah perusahaan harus memiliki tujuan yang jelas. Ada beberapa hal yang mengemukakan tujuan dari berdirinya sebuah perusahaan. Tujuan yang pertama adalah untuk mencapai keuntungan maksimal. Tujuan yang kedua adalah ingin memakmurkan pemilik perusahaan atau para pemilik saham. Sedangkan tujuan perusahaan yang ketiga adalah memaksimalkan nilai perusahaan yang tercermin pada harga sahamnya. Ketiga tujuan perusahaan tersebut sebenarnya secara substansial tidak banyak berbeda, hanya penekanan yang ingin dicapai oleh masing-masing perusahaan berbeda antara yang satu dengan yang lainnya. (Martono dan Harjito, 2011:25).

Secara umum, pasar modal adalah tempat atau sarana bertemunya antara permintaan dan penawaran instrumen keuangan jangka panjang yang umumnya lebih dari satu tahun. Pasar modal merupakan lembaga yang sangat diperhitungkan bagi perkembangan ekonomi negara karena pasar modal menjalankan fungsi ekonomi dan keuangan, maka pemerintah suatu Negara selalu berkepentingan untuk turut mengatur jalannya pasar modal. Perkembangan Bursa Efek Indonesia saat ini tidak dapat dipisahkan dari peran investor yang melakukan transaksi di Bursa Efek Indonesia. Sebelum seorang investor akan memutuskan menginvestasikan dananya di pasar modal (dengan membeli sekuritas yang diperdagangkan di bursa) ada kegiatan terpenting yang perlu untuk dilakukan, yaitu penilaian dengan cermat terhadap emiten, ia harus percaya bahwa informasi yang diterimanya adalah informasi yang benar. Indikator kepercayaan pemodal akan pasar modal dan instrumen-instrumen keuangannya, dicerminkan antara lain oleh dana masyarakat yang dihimpun di pasar modal.

Pendapatan perlembar saham adalah bentuk pemberian keuntungan yang diberikan kepada para pemegang saham dari setiap lembar saham yang dimiliki (Irham Fahmi, 2015:83). Nilai pasar merupakan pembukuan nilai saham di pasar saham dan nilai intrinsic merupakan nilai sebenarnya dari saham (Eva Eko Hidayati, 2010:2). Investor perlu mengetahui dan memahami nilai tersebut sebagai informasi penting dalam pengambilan keputusan invetasi saham karena dapat membantu investor untuk mengetahui saham yang tumbuh dan tidak tumbuh. Salah satu pendekatan dalam menentukan nilai intrinsic saham adalah Earning Per Share (EPS). Dari pengertian diatas EPS atau pendapatan perlembar saham merupakan suatu keuntungan dari setiap lembar saham yang dimiliki yang akan diberikan pada para pemegang saham.

Solvabilitas atau leverage menunjukkan kemampuan perusahaan untuk melunasi seluruh utang yang ada dengan menggunakan seluruh aset yang dimilikinya. Solvabilitas ini untuk mengukur sejauh mana perusahaan dibiayai dengan hutang (Yamit, 2001). Perusahaan yang memiliki rasio solvabilitas rendah mempunyai resiko kerugian yang lebih kecil ketika perekonomian sedang menurun, namun memiliki tingkat return yang rendahpada saat perekonomian tinggi.

Sebaliknya perusahaan dengan rasio solvabilitas tinggi menghadapi resiko kerugian yang besar, tetapi kesempatan mendapat keuntungan juga tinggi. Kesimpulannya adalah bagaimana menyeimbangkan pengembalian yang diharapkan tinggi dengan meningkatnya risiko.

Profitabilitas merupakan rasio yang dapat mewakili kinerja keuangan perusahaan, dimana meningkatnya kinerja keuangan perusahaan akan meningkatkan return yang akan di dapatkan oleh investor. Profitabilitas mengukur kemampuan perusahaan untuk menghasilkan laba. Rasio profitabilitas dalam penelitian ini diwakili oleh Return On Asset (ROA). Rasio ini merupakan rasio yang menunjukkan tingkat pengembalian yang diperoleh pemilik atau pemegang saham atas investasi di perusahaan. Semakin tinggi ROA 
menunjukkan bahwa semakin tinggi tingkat pengembalian terhadap investasi yang dilakukan, sebaliknya semakin rendah ROA suatu perusahaan maka tingkat pengembaliannya akan semakin rendah pula. Tingginya tingkat laba yang diperoleh, maka kemampuan perusahaan untuk membayar dividen juga akan semakin tinggi dan harga saham perusahaan akan semakin meningkat.

Setiap investor pasti mengharapkan tingkat pengembalian yang tinggi dan tidak menginginkan resiko dari investasi yang dimilikinya. Oleh karena itu, investor hanya akan berinvestasi pada sektor yang kurang beresiko. Untuk itu, sebelum memutuskan untuk berinvestasi, investor harus terlebih dahulu memiliki pengetahuan dan pemahaman yang tepat mengenai kinerja perusahaan sehingga dapat dijadikan dasar untuk mengambil keputusan investasi. Untuk membantu investor dalam membuat keputusan investasi, maka perusahaan perlu melakukan pelaporan keuangan. Akuntansi menyajikan informasi mengenai kinerja keuangan perusahaan yang dapat dilihat dari laporan keuangan. Namun, agar memperoleh informasi keuangan yang lebih relevan dengan tujuan dan kepentingan pemakai, maka informasi keuangan tersebut harus terlebih dahulu dianalisis sehingga menghasilkan keputusan bisnis yang tepat. Analisis yang biasa dilakukan adalah analisis laporan keuangan. Salah satu cara yang digunakan dalam analisis laporan keuangan adalah dengan menggunakan rasio keuangan. Rasio keuangan yang digunakan dalam penelitian ini meliputi Rasio Profitabilitas (Return On Asset),

Berdasarkan pada latar belakang yang disampaikan di atas, maka penulis tertarik melakukan penelitian dengan judul "Pengaruh Return On Asset Terhadap Earning Per Share PT. Mandom Indonesia, Tbk Periode 2012-2020”.

\section{B. Rumusan Masalah}

1. Bagaimana Return On Asset pada pada PT. Mandom Indonesia, Tbk ?.

2. Bagaimana Earning Per Share pada PT. Mandom Indonesia, Tbk?.

3. Adakah pengaruh antara Return On Asset terhadap Earning Per Share pada PT. Mandom Indonesia, Tbk?.

\section{Tujuan Penelitian}

1. Untuk mengetahui kondisi Return On Asset pada PT. Mandom Indonesia, Tbk.

2. Untuk mengetahui kondisi Earning Per Share pada PT. Mandom Indonesia, Tbk.

3. Untuk mengetahui pengaruh antara Return On Asset terhadap Earning Per Share pada PT. Mandom Indonesia, Tbk.

\section{METODE PENELITIAN}

\section{Populasi}

Populasi dalam penelitian ini laporan keuangan PT. Mandom Indonesia, Tbk selama 9 tahun

\section{Sampel}

Teknik pengambilan sampling dalam penelitian ini adalah samplel jenuh, dimana semua anggota populasi dijadikan sebagai sampel. Dengan demikian sampel dalam penelitian ini laporan keuangan PT. Mandom Indonesia, Tbk selama 9 tahun.

\section{Jenis Penelitian}

Jenis penelitian yang dipakai adalah asosiatif, dimana tujuannya adalah untuk mengetahui mencari keterhubungan antara variabel independen terhadap variabel dependennya

\section{Metode Analisis Data}

Dalam menganalisis data digunakan, analisis deskriptif, analisis regresi linier sederhana, 
koefisien korelasi, koefisien determinasi dan uji hipotesis.

\section{HASIL PENELITIAN}

\section{Analisis Deskriptif}

Pada pengujian ini digunakan untuk mengetahui nilai minimum dan maksimum nilai tertinggi, rata-rata nilai dan standar deviasi dari masing-masing variabel. Adapun hasilnya sebagai berikut:

Tabel 1. Hasil Analisis Descriptive Statistics

\begin{tabular}{lr|r|r|r|r}
\multicolumn{7}{c}{ Descriptive Statistics } & \\
& $N$ & Minimum & Maximum & \multicolumn{1}{c}{ Mean } & Std. Deviation \\
\hline ROA & 9 & 10.96 & 15.35 & 12.7267 & 1.40647 \\
\hline EPS & 9 & 615 & 1052 & 792.11 & 146.879 \\
\hline Valid N (listwise) & 9 & & & & \\
\hline Return & 9 & & & \\
\hline
\end{tabular}

Return On Asset diperoleh nilai minimum sebesar 615 dan nilai maximum 10.52 dengan rata-rata sebesar $12,72 \%$ dengan standar deviasi $1,40 \%$.

Sedangkan nilai Earning Per Share diperoleh nilai minimum sebesar 615 dan nilai maximum 10.52 dengan rata-rata sebesar 792,11 dengan standar deviasi 146.87.

\section{Analisis Kuantitatif.}

Pada analisis ini dimaksudkan untuk mengetahui pengaruh variabel independen terhadap variabel dependen. Adapun hasil pengujian sebagai berikut:

\section{a. Analisis Regresi Linier Sederhana}

Uji regresi ini dimaksudkan untuk mengetahui perubahan variabel dependen jika variabel independen mengalami perubahan. Adapun hasil pengujiannya sebagai berikut:

Tabel 2. Hasil Pengujian Regresi Linier Sederhana

\begin{tabular}{|c|c|c|c|c|c|c|}
\hline \multicolumn{7}{|c|}{ Coefficients $^{a}$} \\
\hline & & \multicolumn{2}{|c|}{$\begin{array}{l}\text { Unstandardized } \\
\text { Coefficients }\end{array}$} & \multirow{2}{*}{$\begin{array}{c}\text { Standardized } \\
\text { Coefficients } \\
\text { Beta }\end{array}$} & \multirow[b]{2}{*}{$\mathrm{t}$} & \multirow[b]{2}{*}{ Sig. } \\
\hline \multicolumn{2}{|c|}{ Model } & $\mathrm{B}$ & Std. Error & & & \\
\hline \multirow[t]{2}{*}{1} & (Constant) & -106.130 & 372.247 & & -.285 & .784 \\
\hline & ROA & 70.579 & 29.092 & .676 & 2.426 & .046 \\
\hline
\end{tabular}

a. Dependent Variable: EPS

Berdasarkan hasil pengujian pada tabel di atas, diperoleh persamaan regresi $\mathrm{Y}=$ 106,130 + 70,579X. Dari persamaan tersebut dijelaskan sebagai berikut:

1) Konstanta sebesar -106,130 diartikan jika Return On Asset tidak ada, maka telah terdapat nilai Earning Per Share sebesar -106,130 point.

2) Koefisien regresi Return On Asset sebesar 70,579, angka ini positif artinya setiap ada peningkatan Return On Asset sebesar 70,579 point maka Earning Per Share juga akan mengalami peningkatan sebesar 70,579 point.

\section{b. Analisis Koefisien Korelasi}

Analisis koefisien korelasi dimaksudkan untuk mengetahui tingkt kekuatan hubungan dari variabel independen terhadap variabel dependen baik secara parsial maupun simultan. Adapun hasil pengujian sebagai berikut:

Tabel 3. Hasil Pengujian Koefisien Korelasi Return On Asset Terhadap Earning Per Share.

\section{Correlations $^{b}$}




\begin{tabular}{llr|r} 
& & ROA & EPS \\
\hline ROA & Pearson Correlation & 1 & $.676^{*}$ \\
\cline { 2 - 4 } & Sig. (2-tailed) & & .046 \\
\hline \multirow{2}{*}{ EPS } & Pearson Correlation & $.676^{*}$ & 1 \\
\cline { 2 - 4 } & Sig. (2-tailed) & .046 & \\
\hline *
\end{tabular}

*. Correlation is significant at the 0.05 level (2-tailed).

b. Listwise $\mathrm{N}=9$

Berdasarkan hasil pengujian diperoleh nilai korelasi sebesar 0,676 artinya Return On Asset memiliki hubungan yang kuat terhadap Earning Per Share.

\section{c. Analisis Koefisien Determinasi}

Analisis koefisien determinasi dimaksudkan untuk mengetahui besarnya persentase pengaruh dari variabel independen terhadap variabel dependen. Adapun hasil pengujian sebagai berikut:

Tabel 4. Hasil Pengujian Koefisien Determinasi Return On Asset Terhadap Earning Per Share.

\begin{tabular}{|c|c|c|c|c|}
\hline \multicolumn{5}{|c|}{ Model Summary } \\
\hline Model & $\mathrm{R}$ & R Square & $\begin{array}{l}\text { Adjusted R } \\
\text { Square }\end{array}$ & $\begin{array}{l}\text { Std. Error of the } \\
\text { Estimate }\end{array}$ \\
\hline 1 & $.676^{a}$ & .457 & .379 & 115.730 \\
\hline
\end{tabular}

a. Predictors: (Constant), ROA

Berdasarkan hasil pengujian diperoleh nilai determinasi sebesar 0,457 artinya Return On Asset memiliki kontribusi pengaruh sebesar 45,7\% terhadap Earning Per Share, sedangkan sisanya sebesar $54,3 \%$ dipengaruhi faktor lain.

\section{d. Uji Hipotesis}

Pengujian hipotesis dengan uji t digunakan untuk mengetahui hipotesis mana yang diterima.

Rumusan hipotesis: Terdapat pengaruh yang signifikan antara Return On Asset terhadap Earning Per Share.

Tabel 5. Hasil Uji Hipotesis Return On Asset Terhadap Earning Per Share.

\begin{tabular}{|c|c|c|c|c|c|c|}
\hline \multicolumn{7}{|c|}{ Coefficients $^{a}$} \\
\hline & & \multicolumn{2}{|c|}{$\begin{array}{l}\text { Unstandardized } \\
\text { Coefficients }\end{array}$} & \multirow{2}{*}{$\begin{array}{l}\text { Standardized } \\
\text { Coefficients } \\
\text { Beta }\end{array}$} & \multirow[b]{2}{*}{$t$} & \multirow[b]{2}{*}{ Sig. } \\
\hline \multicolumn{2}{|c|}{ Model } & $\mathrm{B}$ & Std. Error & & & \\
\hline \multirow[t]{2}{*}{1} & (Constant) & -106.130 & 372.247 & & -.285 & .784 \\
\hline & ROA & 70.579 & 29.092 & .676 & 2.426 & .046 \\
\hline
\end{tabular}

a. Dependent Variable: EPS

Berdasarkan hasil pengujian pada tabel di atas, diperoleh nilai $\mathrm{t}$ hitung $>\mathrm{t}$ tabel atau $(2,426>2,365)$, dengan demikian hipotesis yang diajukan bahwa terdapat pengaruh yang signifikan atara Return On Asset terhadap Earning Per Share diterima.

\section{Pembahasan Hasil Penelitian}

\section{Kondisi Nilai Variabel Return On Asset}

Berdasarkan data empiris dan analisis data, variabel Return On Asset diperoleh nilai ratarata per tahun sebesar $12,72 \%$.

\section{Kondisi Nilai Variabel Earning Per Share}

Berdasarkan data empiris dan analisis data, variabel Earning Per Share diperoleh nilai rata- 
rata per tahun sebesar 792,11 .

\section{Pengaruh Return On Asset Terhadap Earning Per Share}

Return On Asset berpengaruh signifikan terhadap Earning Per Share dengan persamaan regresi $\mathrm{Y}=-106,130+70,579 \mathrm{X}$, nilai korelasi sebesar 0,676 atau memiliki hubungan yang kuat dengan kontribusi pengaruh sebesar $45,7 \%$, sedangkan sisanya sebesar $54,3 \%$ dipengaruhi faktor lain. Pengujian hipotesis diperoleh nilai $t$ hitung $>t$ tabel atau $(2,426>$ $2,365)$. Dengan demikian hipotesis yang diajukan bahwa terdapat berpengaruh signifikan antara Return On Asset terhadap Earning Per Share diterima.

\section{KESIMPULAN DAN SARAN}

1. Kesimpulan

a. Kondisi variabel Return On Asset berdasar pada periode laporan keuangan 9 tahun diperoleh Return On Asset rata-rata sebesar 12,72\%.

b. Kondisi variabel Earning Per Share berdasar pada periode laporan keuangan 9 tahun diperoleh Return On Asset rata-rata sebesar 792,11.

c. Return On Asset berpengaruh signifikan terhadap Earning Per Share dengan persamaan regresi $\mathrm{Y}=-106,130+70,579 \mathrm{X}$, nilai korelasi sebesar 0,676 atau kuat dan kontribusi pengaruh sebesar $45,7 \%$ sedangkan sisanya sebesar 54,3\% dipengaruhi faktor lain. Uji hipotesis diperoleh nilai $t$ hitung $>t$ tabel atau $(2,426>2,365)$.

\section{Saran}

a. Nilai EPS dapat ditingkatkan dengan meningkatkan laba bersih perusahaan. Ataupun bila laba bersih tetap, dapat disiasati dengan menurunkan jumlah saham yang beredar. Nilai EPS akan meningkat apabila persentase kenaikan laba bersih lebih besar daripada persentase perubahan jumlah lembar saham.

b. Secara akademis, faktor-faktor yang mempengaruhi Harga Saham pada penelitian ini hanya terbatas pada informasi-informasi internal perusahaan yang berdasarkan laporan keuangan perusahaan. Oleh karena itu, disarankan agar penelitian selanjutnya juga menggunakan informasi internal lainnya seperti rasio-rasio keuangan lain dan informasi eksternal perusahaan yang menyangkut kondisi makroekonomi misalnya seperti tingkat inflasi, suku bunga dan lain-lain, selain itu, jumlah sampel dan perusahaan yang diteliti sebaiknya diperbanyak lagi unuk memperkuat hasil penelitian.

\section{DAFTAR PUSTAKA}

Abdul Halim. 2013. Analisis Investasi. Edisi 2. Jakarta: Salemba Empat.

Agus Harjito \& Martono, (2010) "Manajemen Keuangan" Yogyakarta: Penerbit Ekonisia.

Agus Sartono. (2010). "Manajemen Keuangan Toeri dan Aplikasi", Edisi keempat, Yogyakarta: Penerbit BPFE.

Algifari. (2015). “Analisis Regresi untuk Bisnis dan Ekonomi”. Yogyakarta: BPFE.

Arikunto, Suharsimi (2014). "Prosedur Penelitian Suatu Pendekatan Praktek". Jakarta: Rineka Cipta.

Bambang Riyanto, (2011). "Dasar-dasar Pembelanjaan Perusahaan". Edisi ke empat, BPFE Yogyakarta.

Brigham \& Houstan. 2010. Fundamental Of Financial Management. 8th Edition. South Western: Cengage Learning.

Darmadji, T.H.M Fakhrudin. 2012. Pasar Modal di Indonesia Pendekatan Tanya Jawab. 
Salemba Empat, Jakarta.

Fahmi, Irham (2012), "Pengantar Manajemen Keuangan" Cetakan pertama. Bandung: Penerbit Alfabeta.

Fahmi, Irham. 2012. Analisis Laporan Keuangan. Cetakan Kedua. Bandung: Alfabeta.

Hartono, Jogiyanto. 2008. Teori Portofolio Dan Analisis Investasi. Yogyakarta: BPFE.

Hermuningsih, Sri. 2012. Pengantar Pasar Modal Indonesia. Yogyakarta: UPP STIM YKPN. Horne James C. Van dan John M. Wachowicz. 2012. Prinsip-Prinsip Manajemen Keuangan. alih bahasa Dewi Fitriasari dan Deny A. Kwary. Jakarta: Salemba Empat.

Ilham, D. (2014). Implementasi Nilai-Nilai Keagamaan pada Mata Pelajaran Umum dalam Upaya Peningkatan Akhlak Peserta Didik di MAN Malili Kabupaten Luwu Timur (Doctoral dissertation, STAIN/IAIN Palopo).

Ilham, D. (2019). Implementing Local Wisdom Values in Bride and Groom Course at KUA Bara SubDistrict, Palopo City. Jurnal Konsepsi, 8(1), 1-9.

Ilham, D. (2019). Menggagas Pendidikan Nilai dalam Sistem Pendidikan Nasional. Didaktika: Jurnal Kependidikan, 8(3), 109-122.

Imam Ghozali (2017). “Aplikasi Analisis Multivariate Dengan Program SPSS”. Edisi Kelima. Semarang: Badan Penerbit Undip.

Istijanto (2014) "Riset Sumber Daya Manusia". Jakarta: PT. Gramedia Pustaka

Jasmani, J. (2018). Pengaruh Kinerja Keuangan Terhadap Harga Saham (Analisis Pada Perusahaan Property dan Real Estate Yang Go Public di Bursa Efek Indonesia. Jurnal Akuntansi Indonesia, 12(2).

Jasmani, J. (2019). The Effect of Liquidity and Working Capital Turnover on Profitability at PT. Sumber Cipta Multiniaga, South Jakarta. PINISI Discretion Review, 3(1), 29-38.

Kasmir (2010), "Analisis Laporan keuangan", penerbit raja grafindo persada, Jakarta

Kasmir, (2010). "Pengantar Manajemen Keuangan”, Edisi Pertama, Cetakan kedua, Jakarta: Penerbit Prenada Media.

Kasmir. (2012) "Pengantar Manajemen Keuangan”, Edisi Pertama, Cetakan kedua, Jakarta: Prenada Media.

Martono dan Agus Harjito, (2011). "Manajemen Keuangan", Jakarta: Penerbit Ekonisia.

Munawir (2010), "Analisis Laporan Keuangan", Edisi Ke Empat, Penerbit Liberty, Yogyakarta.

Santoso, Singgih (2015). "Menguasai Statistik Multivariat". Jakarta: PT Elex Media Komputindo.

Sartono, "Manajemen Keuangan Aplikasi Dan Teori", Edisi Keempat, BPFE, Yogyakarta, 2008.

Sawir, (2003). “Analisis Kinerja Keuangan dan Perencanaan Keuangan Perusahaan”, Cetakan ketiga, Jakarta: Penerbit PT. Gramedia Pustaka Utama.

Sidharta, I., \& Affandi, A. (2016). The empirical study on intellectual capital approach toward financial performance on rural banking sectors in Indonesia. International Journal of Economics and Financial Issues, 6(3).

Sugiyarso, G. dan F. Winarni, "Manajemen Keuangan (Pemahaman Laporan Keuangan, Pengelolaan Aktiva, Kewajiban dan Modal serta Pengukuran

Sugiyono (2017), "Metode Penelitian Administrasi : dilengkapi dengan Metode R \& D". Bandung: Alfabeta. 